\title{
O pensamento conservador no Amazonas: a interpretação de Arthur Cézar Ferreira Reis sobre a formação do Brasil ${ }^{1}$
}

\author{
Carlos Henrique Gileno ${ }^{2}$ \\ Rodrigo Dantas de Medeiros 3 \\ Ricardo Lima da Silva 4
}

\section{Resumo:}

Considerado um dos maiores historiadores da Amazônia, o amazonense Arthur Cézar Ferreira Reis (1906-93) produziu igualmente obras que analisaram a história brasileira. Nesse sentido, este artigo objetiva estudar a interpretação do autor sobre a formação nacional ao abordar alguns dos seus escritos referentes aos processos de organização do poder da Colônia até a ruptura oligárquica de 1930. As conclusões são de que Arthur Cézar Ferreira Reis possuía uma visão conservadora da história, em que os processos políticos e sociais ocorreriam de maneira lenta e sem rupturas radicais, guiados por uma elite intelectual que defendia a organização institucional e política de um estado planejador e interventor.

Palavras-chave: Pensamento conservador no Brasil; Arthur Cézar Ferreira Reis; formação nacional.

\section{Conservative thinking in the Amazon: the interpretation of Arthur Cézar Ferreira Reis on the formation of Brazil}

\begin{abstract}
:
Considered one of the greatest historians of the Amazon, Amazonian Arthur Cézar Ferreira Reis (1906-93) also produced works that analyzed Brazilian history. In this sense, this article aims to study the author's interpretation of national formation by addressing some of his writings regarding the processes of power organization of the Colony until the oligarchic rupture of 1930. The conclusions are that Arthur Cézar Ferreira Reis had a conservative view. where political and social processes would take place slowly and without radical disruption, guided by an intellectual elite who defended the institutional and political organization of a planning and intervening State.
\end{abstract}

Key words: Conservative thinking in Brazil; Arthur Cézar Ferreira Reis; National formation.

\footnotetext{
${ }^{1}$ Revisão ortográfico-gramatical de Vânia Noeli Ferreira de Assunção.

2 Doutor, membro do Programa de Pós-Graduação em Ciências Sociais e professor da Universidade Estadual Paulista (Unesp/Araraquara).E-mail: cgileno@uol.com.br.

3 Mestrando pela Unesp/Araraquara.E-mail: rodrigo.de.medeiros@hotmail.com.

4 Doutorando pela Unesp/Araraquara. Professor do Instituto Federal do Amazonas (IFAM).E-mail: ricardo.silva@ifam.edu.br.
} 


\section{Introdução}

Na primeira metade do século $\mathrm{XX}$, a região amazônica estava imersa em estagnação econômica que durava desde 1914. Nessa conjuntura, os intelectuais e políticos regionais - oriundos dos grupos dirigentes - arrogaram a si dupla tarefa: analisar as peculiaridades econômicas, políticas e sociais daquela região e organizar projetos de futuro para a superação do subdesenvolvimento. A finalidade primordial daqueles autores e atores políticos era oferecer relevância à região amazônica no cenário nacional, uma vez que havia perdido importância econômica com a decadência do ciclo da borracha (RIBEIRO, 2015).

A interpretação e a atuação política dessa intelectualidade regional estavam corporificadas no escritor, historiador e político Arthur Cézar Ferreira Reis (1906-93). É significativa a importância atribuída por Arthur Cézar Ferreira Reis à organização de um estado interventor e planejador e de uma elite esclarecida capaz de guiar o povo na direção do desenvolvimento e da civilização.

Autor de dezenas de obras referentes à Amazônia, o seu pensamento é tema de vários artigos, dissertações e teses nos dias atuais. Esses estudos procuram compreendê-lo a partir das mais variadas perspectivas da história e do pensamento político e social, colocando-o como o mais representativo defensor da modernização conservadora na Amazônia (RIBEIRO, 2015). Souza (2009 analisa como o autor representou índios, sertanistas e missionários nos processos de colonização do Amazonas, baseado na correspondência do autor e na sua obra inaugural, História do Amazonas, lançada em 1931. Dantas (2011), por sua vez, analisa o processo de construção regional a partir da interpretação de Arthur Cézar Ferreira Reis e da sua contribuição para dar forma às representações correntes sobre a Amazônia. Silva Lobato (2009) estuda como o autor equacionou as dimensões região, estado e nação, apontando para o imperativo de uma ação estatal na região. Gomes (2009) enfoca como foram construídos os movimentos sociais na obra de Arthur Cézar Ferreira Reis, demonstrando a visão conservadora do autor, que os interpreta a partir de duas nuances: aqueles que foram guiados por uma elite esclarecida (o movimento abolicionista e autonomista) e aqueles que, por não terem sido contidos a tempo, resvalaram em excessos e provocaram danos à ordem regional, como a Revolta dos Cabanos (183540). Pacheco (2012), por fim, efetua um estudo da obra de Ferreira Reis ao enfocar o seu nacionalismo e a relação deste com a defesa da Amazônia contida na obra A Amazônia e a cobiça internacional, de 1960.

Apesar de vários aspectos da sua produção sobre a Região Norte serem bastante estudados, há, entretanto, outra dimensão da obra de 
Ferreira Reis que apresenta ponderação escassa: a sua interpretação sobre a formação brasileira. Professor de história nas escolas de ensino médio em Manaus, posteriormente lecionou na Fundação Getúlio Vargas do Rio de Janeiro e na Universidade Federal Fluminense. Nesse espaço de tempo, escreveu dois livros sobre a formação nacional: Épocas e visões regionais do Brasil (1966) e Aspectos da formação brasileira (1982), em que sistematizou conferências e estudos sobre a história nacional.

Essas obras devem ser compreendidas como uma tentativa de Ferreira Reis de criar uma nacionalidade conservadora no Amazonas, chamando a atenção da juventude local para os acontecimentos, estadistas e heróis que, na sua perspectiva, contribuíram para o nascimento do Brasil.

O presente artigo apresenta estudo sobre a visão da formação nacional brasileira na obra de Arthur Cézar Ferreira Reis com base nos dois livros citados. Primeiramente, procuram-se estabelecer os nexos mais gerais dos processos que levaram da colonização à ruptura oligárquica de 1930 e a forma como o autor interpretou a organização do poder institucional e político na sociedade brasileira. Nosso estudo procura evidenciar outra perspectiva ao analisar a interpretação do autor sobre a formação do Brasil e os processos mais decisivos da dinâmica nacional: colonização, independência, abolição, decadência da monarquia constitucional parlamentar e o estabelecimento da Proclamação da República. Em outras palavras, procura-se enfocar como Reis interpreta os processos macro-históricos brasileiros.

De acordo com o intelectual amazônida, o processo histórico da formação nacional está consubstanciado no entrelaçamento de instituições políticas e sociais pretéritas e presentes: a colonização originou a construção da nacionalidade; o mérito do período imperial foi manter a unidade territorial; a I República coordenou uma nova etapa de modernização do país e a Era Vargas pretendeu suplantar a crise do pacto oligárquico. Nesse horizonte teórico estão situados os principais pressupostos da teoria social e política do mencionado autor sobre a constituição da nossa nacionalidade.

O pensamento do historiador em pauta dialoga com uma série de autores e políticos. Em seus escritos, ele apresenta um diálogo com o intelectual francês Émile Durkheim (1858-1917) e suas reflexões sobre coesão e consenso (GOMES, 2009). Também recebe influência do pensamento autoritário brasileiro ao compartilhar as noções da formação brasileira propostas por Francisco José de Oliveira Vianna (1883-1951) e a função do estado nacional como agente privilegiado de organização da sociedade, defendida tanto pelo autor de Instituições políticas brasileiras quanto por Azevedo Amaral (1881-1942). Pertencente à linhagem 
intelectual e política do conservadorismo nacional, foi influenciado pelas vertentes teóricas de alguns membros do Instituto Histórico e Geográfico Brasileiro, principalmente Francisco Adolfo de Varnhagen (1816-78) e João Capistrano Honório de Abreu (1853-1927) (DANTAS, 2011).

Os estudos históricos de A. C. F. Reis pretendiam criar um "sentimento cívico" na juventude que a estimulasse a pensar sobre os problemas políticos e sociais do Amazonas. A sua intenção precípua era a integração e desenvolvimento da Amazônia ao cenário nacional por intermédio de uma missão cívica e patriótica apreendida com o seu mentor, o escritor e político amazônida Álvaro Botelho Maia (1893-1969). Em outra perspectiva teórica, recebeu o influxo do conservadorismo culturalista do pensador pernambucano Gilberto de Mello Freyre (190087), de quem era amigo e admirador (DANTAS, 2011; SOUZA, 2009).

Reis manteve relações pessoais com Gilberto Freyre e Sérgio Buarque de Holanda (1902-1982). Havia discursos elogiosos dos dois autores em relação a nosso autor. Gilberto Freyre - com quem trocava correspondências - convidou-o, inclusive, para participar de conferências na Fundação Joaquim Nabuco. Buarque de Holanda, por sua vez, convidou-o para integrar a coletânea História geral da civilização brasileira (SOUZA, 2009).

Politicamente, existe em Reis uma forte carga nativista de valorização da história do Amazonas, seus heróis e estadistas. O autor se preocupava em alertar a juventude e tirá-la de uma suposta letargia em relação ao ambiente cultural e aos problemas do Amazonas. Essas ações consolidaram a liderança de nosso autor entre os jovens em Manaus, rendendo-lhe o apelido de "mestre dos moços". Essa preocupação com a formação política da juventude, ele a herdou do escritor e Político Álvaro Maia5, que exerceu grande influência sobre ele durante sua juventude e que procurava, conforme apresentou em seu discurso Canção de fé e esperança, restabelecer a verdade e revelar quem eram os benfeitores e difamadores do Amazonas (SOUZA, 2009).

A formação da nacionalidade, para Reis, está vinculada a um processo linear que começa com a colonização, desconsiderando as civilizações locais que existiam antes da conquista europeia. A criação da nação brasileira resulta da dinâmica evolutiva iniciada com os processos de dominação no século XVI, processos que vão redundando no efetivo florescimento do Brasil como entidade política. Privilegia em sua perspectiva não o povo, visto como uma entidade amorfa e desorganizada, mas os grandes movimentos do estado, seja o português durante a colônia,

5 Álvaro Botelho Maia (1893-1969) foi governador do Amazonas entre os anos de 1930-3; 1935-45; 1951-5. Foi autor de obras como Beiradão (1958), Defumadores e porongas (1966) e Nas tendas dos Emaús (1967). 
seja o brasileiro após 1822, bem com a ação dos estadistas e dos heróis nacionais. Em sua obra, prevalece uma visão da formação nacional amparada por uma elite - seja política ou intelectual - e pela ação privilegiada do estado como ente capaz de criar e organizar uma sociedade.

Para compreender a visão conservadora da história de Arthur Cézar Ferreira Reis, é necessária breve descrição dos principais aspectos teóricos que compõem a organização do pensamento conservador, principalmente no Brasil.

\section{Breves considerações sobre o pensamento conservador}

Do mesmo modo que o liberalismo e o socialismo, o conservadorismo é um estilo de pensamento que nasce e se desenvolve na modernidade como reação às mudanças capitaneadas pelo Iluminismo europeu (MANNHEIM, 1972). A obra Reflexões sobre a revolução na França (1790) contraditava a concepção de que a Revolução Francesa integrara as virtudes da Revolução Gloriosa inglesa de $1688^{6}$.

A Declaração de direitos britânica de 1688 garantiu a liberdade, a vida e a propriedade privada dos súditos contra os possíveis abusos do absolutismo real e estabeleceu as regras para a sucessão do trono inglês. Edmund Burke demonstrou que o parlamento, mesmo em caso de grave crise política, jamais anulou o princípio da hereditariedade do poder real. Houve obediência do Parlamento aos "antigos estatutos declaratórios", visto que rei e povo constituíam o mesmo corpo político.

O compromisso ou pacto social, que se conhece geralmente como Constituição, proíbe tal violação e tal rendição. As partes constituintes de um estado estão obrigadas a respeitar as obrigações públicas que têm umas com as outras, bem como todos aqueles compromissos dos quais derivam interesses importantes, da mesma forma que o estado, como um todo, é obrigado a cumprir seus compromissos com as comunidades particulares (...). (BURKE, 2014, p. 43)

Conforme Edmund Burke, aquela Declaração circunscreve o poder da coroa, mas o princípio da hereditariedade do monarca resta intocável: não engendrou os "inesperados giros da roda da fortuna" personificados nas revoluções típicas do período do Terror francês (1793-4). Antes, a Declaração de direitos - que seria a base do Bill of Rights de 1689 - foi um pacto que confirmou os direitos e as liberdades dos ingleses, ao mesmo tempo em que regulou a sucessão da coroa. Ao invés de destruir antigos

${ }^{6}$ Reflexões sobre a Revolução na França é um livro clássico do intelectual e político irlandês Edmund Burke (1729-97), que posteriormente influenciou o pensamento conservador. Edmund Burke propugnava a ideia de que a influência da Revolução Gloriosa (1688-9) no imaginário dos revolucionários franceses é confusa por não entenderem os fundamentos da Declaração de direitos produzida pelos ingleses. 
direitos fundados e legitimados pelo Common law, a Revolução de 1688 foi uma reforma constitucional que assentou o "patrimônio legal já existente e herdado", ao garantir a legitimidade do poder dos reis europeus.

O pensamento conservador pode ser entendido como tentativa de resposta racional à preservação de determinadas heranças coletivas. Edmund Burke criticava as relações de troca e monetárias que emergiram da revolução burguesa na França, porquanto aquelas relações deveriam ser dependentes de uma ordem econômica que precisaria estar submetida a uma ordem moral. Essa mesma ideia estava contida na Teoria dos sentimentos morais (1759) do filósofo e economista escocês Adam Smith (1723-90), contemporâneo de Edmund Burke. As maneiras ou a ordem moral dizem respeito à confiança, à responsabilidade e ao compromisso.

A deferência aos atributos morais é que funda a solidariedade humana. A solidariedade, o dever e a virtude são a "mão invisível” que guiará os interesses individuais para a realização da legítima satisfação coletiva. Assim, o ser humano não é simples homo economicus e a política não pode ser apêndice da economia e tampouco de estratégias políticas de facções ideológicas. Essa crítica é dirigida ao economicismo do capitalismo moderno, o qual comete duplo equívoco: 1) Reduzir a ordem política às operações do mercado; 2) Em determinados períodos históricos, gerar rupturas revolucionárias que reduzem a política à manutenção de um único projeto de poder.

Nesse contexto intelectual burkiano, a sociedade é dependente das relações de afeto e lealdade que só podem ser erigidas de baixo para cima, na interação face a face entre os indivíduos. Essas relações se desenvolvem na família, nos clubes locais, nas associações, nas instituições de ensino e religiosas, no ambiente de trabalho, entre outros. É justamente nesses ambientes que o ser humano interage proximamente com os seus semelhantes, "assumindo a responsabilidade por seus atos e levando em consideração o próximo” (SCRUTON, 2014, p. 40).

Edmund Burke enfatizou que sãos os costumes e as tradições que fundam os vínculos de solidariedade de baixo para cima. Quando uma sociedade não é organizada segundo os costumes do povo, mas ordenada de cima para baixo por uma ditadura revolucionária ou pela burocracia impessoal ávida de colocar decretos em execução, o respeito e a solidariedade que uniam os indivíduos são desfeitos.

Assim, governos centralizados que impõem regras de cima para baixo geram a irresponsabilidade entre os indivíduos, ao mesmo tempo em que o monopólio da burocracia impessoal sobre a sociedade faz surgir nas pessoas a carência do agir livre. Portanto, as tradições sociais não são costumes adotados arbitrariamente pela sociedade, mas formas de 
conhecimento que - pelos caminhos dos erros e acertos no decurso histórico - sistematizaram tentativas de ajustar as condutas dos indivíduos entre si. Dessa forma, “(...)caso as destruamos de modo negligente, eliminaremos as garantias oferecidas de uma geração para a geração posterior" (SCRUTON, 2014, p. 40).

$\mathrm{O}$ pensamento conservador intenta aliar as exigências da permanência de determinadas tradições e costumes com as exigências da mudança histórica. Não deve pretender destruir tudo o que foi construído pelas gerações anteriores de maneira irrefletida, mas preconizar a mudança "refletida e moderada" (KIRK, 2013).

Nessa perspectiva, o pensamento conservador elabora crítica ao culto do progresso desmedido que está impresso na subjetividade progressista moderna: se o pensamento progressista considera o presente como o início do futuro, o pensamento conservador concebe o futuro "como o mais avançado estágio alcançado pelo passado" (RICUPERO, 2013, p. 76). O passado coexiste com o presente e, diferentemente do pensamento progressista, a ideia central para o pensamento conservador não é a de sucessão constante de modos de vida, porém a coexistência de estilos de organizações sociais pretéritas e presentes.

\section{Particularidades do pensamento conservador no Brasil}

No Brasil e na América Latina, o pensamento conservador teve a sua origem na negação do passado colonial. Nas revoluções de independência, o pensamento conservador latino-americano seguiu caminho diverso do europeu, que fustigava a Revolução Francesa à moda de Edmund Burke. A nova ordem política que emergia das revoluções de independência nas Américas estava impossibilitada de conservar partes das suas relações políticas e sociais pretéritas.

Em poucas palavras, é muito difícil, como já foi dito, para conservadores na América valorizar o passado porque esse passado é o passado colonial. Aceitá-lo seria, no limite, valorizar a dominação das antigas metrópoles e pôr em questão a própria independência. (RICUPERO, 2013, pp. 78-9)

Aquele mundo em profunda transformação na América Latina fez que o pensamento conservador não se voltasse para a manutenção de valores e sentimentos compartilhados pela sociedade ao longo dos séculos. As respectivas condições de colônia dos territórios latino-americanos experimentaram os valores e as leis impostos de cima para baixo pelas metrópoles, sendo rara a presença do pensamento conservador clássico europeu na América Latina7. O pensamento conservador no Brasil se

7 Na América Latina não havia, como na Inglaterra, a vigência do Common Law. 
deparou com o fato de ser uma colônia que almeja a independência, afastando-se da ideia do conservadorismo clássico, que valorizava determinadas instituições políticas e sociais geradas pelos séculos anteriores.

Roberto Schwarz (1988), no seu texto sobre a obra do escritor Machado de Assis (1839-1908), assinalou que o liberalismo é uma ideia fora do lugar no Brasil. O socialismo e o conservadorismo igualmente se constituem em ideias fora do lugar, levando-nos a problematizar as mudanças que as influências intelectuais e teóricas sofrem ao serem recepcionadas em diferentes ambientes econômicos, políticos e sociais.

No livro publicado em 1965, A consciência conservadora no Brasil: contribuição ao estudo da formação brasileira, o filósofo e jurista Paulo Mercadante (1923-2013) afirmava que no Brasil o pensamento conservador se ancorou no ecletismo filosófico ${ }^{8}$. Serão diversas as bases teóricas que compuseram aquela consciência, com os intelectuais e políticos trazendo consigo a ideia do "reformar para conservar" ao aperfeiçoarem "um estilo específico de pensamento, correspondente à peculiaridade de suas origens sociais” (MERCADANTE, 1980, p. 218).

As origens sociais do pensamento conservador nacional estavam localizadas no domínio rural e na incipiente burguesia urbana, vinculada aos interesses de exportação. Esses homens públicos nortearam o seu pensamento pela ação coletiva fundada na exportação e no domínio rural. Todavia, existiam certas peculiaridades inerentes àquele domínio: a elite não formou castas, com o acesso à vida pública sendo dependente da confiança do grupo dominante. Para ingressar na magistratura, na administração pública, na política ou no magistério, o indivíduo podia tornar-se membro do partido conservador ou liberal, desde que no seu espírito predominasse a moderação.

Os senhores rurais brasileiros estavam em um contexto de liberalismo econômico insuficiente e de liberalismo político em antagonismo com o trabalho escravo. Dessas condições institucionais e materiais é que surgiram o ecletismo filosófico e o espírito de conciliação política entre os grupos dominantes. Nesse caso específico, havia a necessidade de conciliar a revolução nas relações externas "com o escravismo nas relações internas de produção": conciliação que era a principal questão apresentada às elites que realizaram a Independência de 1822. Historicamente, todo pensamento que se opunha às reformas graduais da escravidão foi solapado até 1870 , fase em que o movimento

8 O ecletismo é uma diretriz teórica originada na Antiguidade grega, e retomada ocasionalmente na história do pensamento, que se caracteriza pela justaposição de teses e argumentos oriundos de doutrinas filosóficas diversas, formando uma visão de mundo pluralista e multifacetada. 
abolicionista se intensificou, acompanhado da conciliação política entre as elites dominantes.

Defendia, por todo o longo percurso de sua preeminência política, o instituto da escravatura e o liberalismo econômico, procurando ajustá-los ambos à realidade política de um país novo e composto de diferentes regiões. (MERCADANTE, 1980, p. 221)

O liberalismo econômico se consagrou harmonizando-se às relações internas de produção sustentadas pelo trabalho compulsório. Igualmente, o liberalismo político ignorava a vigência da instituição escravocrata. Em verdade, a ideologia nacional conservadora teve a sua gênese no liberalismo econômico do final do século XVIII, mas não se associou a qualquer tipo de pensamento político radical.

Se a Restauração (1814-30) na França foi realizada em sociedade extenuada pelo jacobinismo impregnado de extremismo revolucionário, a independência política no Brasil não seguiu o pensamento radical da Revolução Francesa em seu todo: ao contrário, a questão da emancipação política ficou subordinada às melhorias das relações entre a metrópole e a colônia, causando "um ajuste de interesses" (MERCADANTE, 1980, p. 227).

Ao refletirmos sobre as diferenças de desenvolvimento do pensamento conservador europeu que partiu de Edmund Burke e a constituição do pensamento conservador nacional, podemos inferir que é temerário - do ponto de vista conceitual e da prática política - utilizarmos conceitos de forma abstrata. O pensamento conservador assumiu determinadas particularidades no Brasil, consistindo em uma força social e política que comandou o processo de desenvolvimento da modernização conservadora após a independência política de 1822.

A análise das obras intelectuais de referência, da ação política, dos discursos e dos debates parlamentares deve ser objeto de estudo premente para compreendermos aspectos conceituais importantes de um pensamento que se destaca na vida pública nacional.

\section{O pensamento conservador de Arthur Cézar Ferreira Reis}

Ao ponderar sobre as raízes intelectuais brasileiras, o historiador mineiro João Camilo de Oliveira Torres (1915-73) assim definiu o pensamento conservador:

Uma posição política que reconhece que a existência das comunidades está sujeita a determinadas condições e que as mudanças sociais, para serem justas e válidas, não podem quebrar a continuidade entre o passado e o futuro. Podemos dizer que o traço mais característico da psicologia conservadora consiste, exatamente, no fato de que não considera viáveis as 
transformações e mudanças feitas sem o sentido da continuidade histórica (...) (TORRES, 2017, p. 23).

Essa descrição se aproxima de alguns aspectos teóricos encontrados na obra de Arthur Cézar Ferreira Reis. No livro Os construtores do império: ideias e lutas do Partido Conservador Brasileiro (1968), João Camilo de Oliveira Torres propôs comparação crítica do pensamento conservador com posições que aparentemente lhe seriam similares, como o imobilismo social ou político, o reacionarismo e o progressismo. Segundo o autor mineiro, o imobilismo se conforma com a situação política e social hodierna ao rejeitar qualquer transformação, a despeito de ser legítima ou benéfica.

O reacionarismo defende o "refluxo" do tempo histórico ao condenar as transformações ocorridas recentemente, reivindicando o retorno às origens identificadas a um idealizado "passado de glórias". $\mathrm{O}$ progressismo geralmente é caracterizado pelo pensamento revolucionário, que funda a sua concepção da realidade social na ideia de sucessão histórica inexorável que substitui ininterruptamente a antiga ordem social. Nesses termos, o progressismo se diferencia substancialmente do imobilismo e do reacionarismo, que propugnavam a noção de que a suposta ordem social a ser fundada corromperia as virtudes das instituições políticas e sociais anteriores.

Diversamente do imobilismo, progressismo ou reacionarismo, a essência teórica do conservadorismo compreende que, em determinadas condições históricas algumas mudanças políticas e sociais podem ser virtuosas, desde que não se oponham de forma irrefletida e radical às instituições mantenedoras do legado benéfico das gerações precedentes (TORRES, 2017). Sendo assim, o conservadorismo não é refratário à mudança, ao contrário das visões estanques e passadistas do imobilismo e do reacionarismo; antes, o pensamento conservador possui cautela perante a mudança insensata, a qual deve ser norteada pela prudência política platônica (KIRK, 2013).

Aquelas definições de conservadorismo estabelecem estreitas ligações com os pressupostos teóricos do pensamento de Arthur Cézar Ferreira Reis, os quais indicam que o processo histórico deve ser transformado de maneira gradual, para evitar os traumas advindos das rupturas revolucionárias. $\mathrm{O}$ projeto de futuro do intelectual e político amazônida procurava conciliar as relações sociais pretéritas e presentes, ao intentar refletir sobre temas e problemas políticos e sociais que se desenrolavam em cenários históricos concretos e específicos.

A linhagem intelectual de Arthur Cézar Ferreira Reis pode ter o seu início nas ideias representadas pelo Partido Conservador do império brasileiro (Saquaremas), o qual não era um partido reacionário em sua 
essência, apesar de algumas de suas alas internas combaterem qualquer forma de progresso (TORRES, 2017).

O conservadorismo no Brasil do século XIX tinha como expoentes José da Silva Lisboa, visconde de Cairu (1756-1835); Honório Hermeto Carneiro Leão, marquês do Paraná (1801-56); Paulino José Soares de Sousa, visconde do Uruguai (1807-66) e José Antônio Pimenta Bueno (1803-78), entre outros. Para esses intelectuais e políticos, a nação é formada por indivíduos livres que possuem direitos civis e políticos; são portadores inclusive de direitos que antecedem a formação do próprio estado moderno, como os direitos naturais. Porém, a nação brasileira articula na sua própria historicidade os direitos específicos que a diferenciam de outras nações e que acentuam a sua realidade particular (TORRES, 2017).

Os "saquaremas" tinham como dogma fundamental que a liberdade somente está devidamente protegida se encontra o apoio de uma autoridade forte e imparcial. Contra a tendência ao anarquismo que as doutrinas de Rousseau possuíam em estado latente, fundando a liberdade na ausência de poder, na abolição de qualquer ordem ou categoria social, os conservadores postulavam o princípio de que os cidadãos não poderiam ser livres senão sujeitos à lei, a uma autoridade justa, neutra, imparcial, soberana, que fizesse a todos justiça reta e igual. (TORRES, 2017, p.31)

Esta defesa dos saquaremas de uma autoridade forte e imparcial era o pilar do conservadorismo imperial e pode ser associada ao pensamento político e social de Reis. Considerado por alguns críticos representante da vertente política "autoritária", na realidade era o conservadorismo que guiava as suas ideias e práticas políticas.

Reis é legatário do pensamento conservador amazônida, cuja particularidade só pode ser compreendida dentro do contexto de crise da economia extrativista da primeira metade do século XX e da tentativa das elites locais - e dos intelectuais - de organizarem novos caminhos para o desenvolvimento regional. O resultado dessa empreitada política e intelectual foi a defesa de um nacionalismo exaltado que procurava determinar o lugar que a Amazônia deveria ocupar no Brasil. Nesse panorama, ocorreu a apoteose de um estado interventor e planejador, com a tarefa de reformar uma sociedade amorfa ao guiar um povo supostamente incapaz de auto-organização. Essas concepções teóricas de Reis originaram a sua afinidade eletiva com o bloco de poder que tomou o poder a partir de 1964 . 


\section{A colonização portuguesa e a gênese do nacionalismo no Brasil}

O tema do nacionalismo é característica marcante da obra histórica de Arthur Ferreira Reis. Ao narrar uma versão da história que conseguisse despertar na juventude o sentimento de patriotismo, o autor procurou na sua pesquisa documental indícios empíricos que atestassem com veracidade os aspectos essenciais do desenvolvimento histórico brasileiro.

Reis presumia que a formação política e social brasileira era consequência imediata da colonização europeia na América, África e Ásia. O surgimento da modernidade se deu a partir do processo da expansão colonial europeia, denominada pelo autor de "europeização do mundo", considerada a maior revolução empreendida pela humanidade. Nesse cenário, Reis empreendeu a apologia ao espírito expansionista europeu, em especial ao expansionismo marítimo português, que havia ampliado as possibilidades dos europeus de conquistar as terras de além-mar.

A civilização do Novo Mundo pelos europeus permitiu o surgimento do ímpeto de liberdade que incentivou os povos do continente americano a lutar pela independência política no final do século XVIII e início do século XIX. Desse modo, Reis estabeleceu uma continuidade linear entre a expansão europeia, a colonização e a independência das colônias americanas. A consolidação da independência dos países latinoamericanos foi inspirada pela Revolução Americana de 1776 e pela Revolução Francesa de 1789, as quais despertaram sentimentos de liberdade que ainda poderiam ser encontrados nos anos 60 do século XIX no Brasil (REIS, 1966)9.

Reis narra em forma de epopeia os acontecimentos do descobrimento, conquista, domínio e colonização da América pelos lusitanos. Ao superar inúmeros perigos, sofrer derrotas e vencer lutas épicas, os portugueses provaram a sua capacidade adaptativa, que permitiu a formação do Brasil. Os primeiros três séculos da colonização se firmaram pela presença do português, que construiu uma "sociedade viril" e miscigenada.

\footnotetext{
Desde os primeiros momentos, os que desembarcavam no litoral, ao tomar contato com o meio social, encontrando a humanidade feminina local a ela foi se ligando intensamente, com o que deu origem a um núcleo social novo, mestiço, integrado nos rigores do meio físico e incontestavelmente, por essa adaptação, indicado para a realização de toda uma série de empreendimentos que exigiam a identificação com tais rigores. $\mathrm{O}$ processo de acomodação dos reinóis (...) foi lento e
}

9 Provavelmente o autor está se referindo à chamada Revolução de 1964, da qual foi um dos apoiadores ao considerá-la movimento político que lutou contra a corrupção e pela moralização do país. Sobre esse assunto consultar Reis (1968). 
continuado. Efetuou-se ora livremente, sem nenhum respeito às regras legais, ora sob o impulsionamento e a rigidez dos estatutos de direito, sempre, porém, sob o aplauso do estado, que compreendera a conivência da solução. (REIS, 1966, p. 27)

A colonização portuguesa foi resultado de três séculos, sendo o principal processo de adaptação a mistura dos reinóis com as indígenas. Essa miscigenação ocorria de forma espontânea ou era incentivada e regulada pelo estado metropolitano. Paulatinamente, a metrópole portuguesa compreendia a natureza geográfica e social da colônia e elaborava políticas públicas que incentivassem a miscigenação dos lusitanos com os autóctones. Do mesmo modo, Reis destacou os cinco milhões de africanos escravizados que foram trazidos para a colônia, resultando na estrutura básica da sociedade colonial. Essa composição étnica seria o arrimo que gestaria, no último quartel do século XVIII, uma sociedade que mais tarde conquistaria a sua autonomia política (REIS, 1966). Resumindo, essa seria a concepção linear da história e da autonomia política brasileiras vistas a partir de um processo cumulativo e evolutivo.

A atividade econômica do período colonial foi organizada pelo planejamento estatal na forma de estatutos, dispositivos, portarias, leis e levantamentos. O planejamento econômico se fazia necessário, pois caso contrário redundaria no caos econômico e na decadência da nação portuguesa. A Colônia foi dividida em quatro áreas geoeconômicas: 1) A Amazônia ficaria com o sistema extrativista das drogas do sertão, concedendo prêmios aos que se destacassem no cultivo da terra, bem como penalidades àqueles que burlassem leis de preservação; 2) O Nordeste produziria açúcar, ao incentivar o aumento da área canavieira e assegurar normas para a sua produção ordenada e facilidades para aprimoramento da técnica; 3) O Sul privilegiaria o pastoreio, regulando a importação e exportação de bens; 4) O Sudeste incentivaria a mineração com políticas de imigração e promoveria a reforma dos processos de extração. Segundo Reis, em cada uma dessas regiões se definiram condições próprias, demonstrando que o estado metropolitano procurava se adaptar aos ciclos históricos que se modificavam no decorrer do tempo (REIS, 1966).

O poder político português agiu de maneira organizada ao planejar, incentivar, regular ou restringir a ação humana na colônia. A administração da sociedade colonial foi realizada pela ação coordenada e realista do estado metropolitano, demonstrando a capacidade de adaptar a sua ação conforme a conjuntura. Reis mencionou a constituição centralizadora do Governo Geral e a virtuosa atuação administrativa e política de Tomé de Sousa (1503-79), a qual resultou na organização eficiente da colônia ao unir os povoados e as regiões, pondo termo à dispersão que perdurara nas capitanias. 
O governo de Tomé de Sousa não era baseado no improviso, mas normatizado em regimentos detalhados. Em seguida, Reis apontou a reforma que instituiu o Conselho Ultramarino originado da União Ibérica. As dificuldades que surgiram a partir de 1573 criaram a necessidade de acabar com o expediente do governo único na colônia, bipartindo aquele poder entre o Norte e o Rio de Janeiro (REIS, 1966). Esse caráter adaptável da política colonizadora ofereceu vantagem aos portugueses sobre outros povos no exercício do poder nas suas respectivas colônias.

A. C. Ferreira Reis procurou sustentar a seguinte tese: a colonização portuguesa foi norteada por engenhoso planejamento estatal herdado pela monarquia constitucional parlamentar e, ulteriormente, pela República Federativa, visto que aquele planejamento estava materializado em uma política realista que se adaptava ao meio social e geográfico no transcorrer dos séculos.

Porque planejamento não é coisa de nossos dias, como muitos
imaginam. É velho, dos primeiros tempos da vida social,
naturalmente sem as exigências que condicionam ou
caracterizam os planejamentos atuais. Compreendido o
planejamento como uma ideação a ser posta em prática através
de uma política continuada, sem interrupções, política efetiva,
realística, evidentemente não será demais concluir - que a
formação territorial do Brasil foi, senão totalmente, em grande
parte resultando de um plano nacional português (REIS, 1966,
p. 89).

A partir do século XVIII começou a se fortalecer um sentimento nativista na cultura e na política, desembocando na independência da América colonial portuguesa. Aquele sentimento teria surgido devido à ineficiente administração pública dos governantes, que não obedeciam às ordens e leis provenientes da coroa. As reclamações que os colonos enviavam à metrópole evidenciavam que eles já tinham consciência dos seus direitos. Nesse ínterim, Reis descreveu a influência das ideias revolucionárias francesas na colônia, as quais provocaram revoltas que reivindicavam a independência política e a implantação da república (REIS, 1966; 1982).

Em contrapartida, o autor ressaltou que o caráter regional do Brasil era uma das peculiaridades da formação nacional. Durante a história brasileira, o estado forte e interventor esbarrou nas enormes distâncias que separavam as províncias e que acarretavam consideráveis dificuldades nas comunicações. Esses fatores reforçaram o nosso caráter regional. A metrópole portuguesa entendeu essa característica e adaptou a sua política ao seu vasto território colonial ${ }^{10}$.

$10 \mathrm{O}$ autor assinala a capacidade organizativa do poder público português em criar um novo mundo ao mesmo tempo em que procura se adaptar à realidade geográfica, cultural e política. 
Apesar dos eventuais erros políticos cometidos pelos colonizadores lusitanos, Reis indicou que o processo de colonização foi positivo porque serviu a um propósito maior: a construção de uma nova nação nos trópicos americanos. Diante desse objetivo épico, todo e qualquer abuso provindo de sertanistas, planejadores governamentais locais ou da oligarquia latifundiária poderia ser colocado sob suspeição. O governo metropolitano entendia, segundo o historiador amazônida, que o Velho Mundo deveria compor o Novo Mundo ao ampliar o seu domínio colonial.

(...) obedeceu a um propósito político, resultou de um programa. As ordens régias, as decisões do Conselho Ultramarino são abundantes dentro dessa finalidade. Buscouse, no Sul, o Prata. A Colônia do Sacramento materializou o Forte do Presépio, que deu origem a Belém, e a Macapá, assinalaram a marcha dos sertanistas, dos pioneiros, dos fronteiros. A expansão para o Oeste levou a Minas, a Goiás, a Mato Grosso e à hinterlândia amazônica (REIS, 1966, p. 53).

Esse intuito político da metrópole conduziu à execução de um planejamento administrativo e político e firmou a necessidade de fomentar base econômica que tornasse possível a vida social na colônia. Assim, foram engendradas a criação de gado, a produção do açúcar e a extração das drogas do sertão. Na perspectiva de Reis, Portugal conseguiu levar a cabo uma das experiências de aclimatação mais bem-sucedidas da história do ocidente europeu, pois conseguiu constituir uma sociedade orgânica e sólida na colônia. Essa política realista que visava a formar e disciplinar a vida econômica, política e social na colônia tinha também como instrumento o inventário:

das atividades construtivas que, para uma compreensão mais penetrante, mais aguda de nosso processo de colonização, precisa envolver-lhe os aspectos político-administrativos e de cultura, de espiritualidade em que os portugueses agiam com objetividade, encontra, todavia, no que diz respeito à estrutura social, a contribuição primordial da participação portuguesa na nossa fundamentação. Porque foi através da formação de uma sociedade, capaz de entender-se bem com o meio agressivo que Portugal pôde realizar seu programa de aproveitamento do Brasil, seja no que diz respeito a sua configuração territorial, seja no que diz respeito aos processos econômicos (REIS, 1966, p. 539)

Ao refletir sobre o tipo social de colono que desembarcou no Brasil, Reis - no livro A política de Portugal para o Vale Amazônico - afirmou que os colonos derivavam tanto de uma pequena nobreza quanto de homens honestos, sendo apenas uma ínfima parte formada por criminosos. A asserção comumente veiculada de que os colonos eram todos foras da lei degredados era uma tentativa de maldizer as raízes portuguesas do Brasil. Em verdade, Reis indicou que a base dos colonos 
era formada por uma pequena nobreza, lavradores, artífices, artesãos, mestres, nobres, "pescadores, tecelões, armeiros, funcionários públicos, soldados e letrados" (REIS, 1966).

Arthur Reis também apresenta reflexão positiva a respeito da ação na colônia da Igreja Católica, considerada apêndice fundamental para o disciplinamento espiritual tanto do nativo quanto do colono. A religião possui importante função social de moderação das paixões, principalmente no ambiente agreste e desagregador da colônia. A Igreja Católica desempenhou relevante papel na formação da nacionalidade ao regular a conduta humana e tornar a vida social possível. Mesmo com a expulsão dos padres da Companhia de Jesus pelo marquês de Pombal, considerado por Arthur Reis um estadista modelo, a presença religiosa se manteve com as atuações do clero secular e dos padres da Ordem dos Capuchinhos (REIS, 1966). De fato, segundo o autor, a história brasileira foi digna de admiração nos seus primeiros três séculos:

\begin{abstract}
a história dessa formação territorial, realizada sem cessar por nós próprios, por decisão local, posteriormente coberta na expedição de atos políticos que legalizavam a expansão e asseguravam o futuro político dessa irradiação espetacular, é bem o termo (...). Porque só mesmo um povo de gigantes, desprovido dos recursos técnicos que não existiam então, poderia ter efetuado a portentosa façanha (REIS, 1982, p. 110).
\end{abstract}

O autor amazônida louvou esse processo de expansão territorial como um acontecimento de proporções épicas: a sua intenção era interpretar as raízes da nacionalidade como uma façanha que deveria servir de referência para as gerações mais novas. Os supostos abusos contra os mais fracos e os derrotados que porventura pudessem ter acontecido são postos em segundo plano. O objetivo é reverenciar a formação nacional que - apesar de realizada em condições tão precárias resultou no feito incrível de criar um país com enorme extensão territorial e diversidade de etnias, costumes e culturas.

\title{
6. A independência e o império na visão conservadora de Arthur Cézar Ferreira Reis
}

A partir de 1750, o Brasil crescia em importância econômica e política, pois o poder colonial português se concentrava não mais nas suas colônias do Oriente, e sim nas suas possessões do Ocidente (REIS, 1966, p. 51). Arthur Cézar Ferreira Reis descreveu a decadência da economia portuguesa no século XVIII: o ouro brasileiro não mais oferecia os mesmos dividendos, sendo substituída a extração aurífera pela produção agrícola e pelo extrativismo vegetal. As reformas do marquês de Pombal consideradas positivas pelo autor - foram baseadas no incentivo à 
indústria e à iniciativa privada, porém não conseguiram estancar o processo de decadência econômica portuguesa (REIS, 1982).

Em contrapartida, Reis apresentou a vinda da família real portuguesa como acontecimento imprescindível para assegurar novo status de civilização ao Brasil, que estava então modernizando as suas principais cidades e recepcionando novos valores culturais e políticos da Europa. Nesse contexto, as ideias liberais percorreram livremente o Brasil, sendo parte de um movimento maior de descolonização do mundo atlântico, do qual o país seguiria o caminho:

principiou a transformação no sistema existencial, adotando-se fórmulas revolucionárias, ideologias avançadas, princípios que feriam práticas centenárias, fórmulas políticas também já vencidas pelo tempo. O chamado Iluminismo, da filosofia reformadora, envolvendo círculos pensantes e mesmo círculos responsáveis pelos destinos políticos dos povos, marcou a crise de que a Enciclopédia seria o fruto mais profundo (REIS, 1982, p. 127).

Arthur Cézar Ferreira Reis afirmava que o processo de independência ocorreu de maneira natural e sem rupturas radicais. A Carta Constitucional de 1824 - outorgada pelo imperador D. Pedro I - foi mais liberal do que a proposta pela extinta Assembleia Constituinte de 1823. As insatisfações populares ocorridas logo após a Independência são tomadas como fenômeno natural, isto é, como episódio esperado para um país que tinha acabado de conquistar a independência (REIS, 1966).

Assim, o império tomou a forma unitária. A Constituição preferiu dar ênfase à unidade do território em detrimento das peculiaridades regionais, espremendo as aspirações das regiões. A monarquia constitucional parlamentar, com seus dois partidos, o conservador e o liberal, não se diferenciavam no exercício do poder (REIS, 1966; 1982). Efetivamente, Arthur Reis era crítico do parlamentarismo, considerando-o mais um jogo de poder do que um meio para atender aos interesses do país; foi uma experiência que pouco contribuiu e não criou raízes na política brasileira. Era o imperador, com o seu poder pessoal, muito mais efetivo na condução da vida nacional. Reis apontou que a projeção que o Brasil alcançou no século XIX foi digna de nota:

Decorre de seu desenvolvimento econômico, de seu processo político ordeiro, de suas instituições liberais em funcionamento regular. As relações que manteve com outros povos foram relações exercidas em termos de igualdade e asseguradas em sua plenitude através de atos diplomáticos que regularam, no particular da Sul-América, limites, boa vizinhança, comércio e comunicações. (REIS, 1966, p. 67)

A respeito da análise da forma de organização do estado tomada pelo Brasil a partir da Carta Constitucional de 1824, Reis converge com 
Oliveira Vianna ao afirmar que a forma unitária era a mais correta, por ter mantido o território unido, dialogando com o ensaio Os regionalismos e a unidade nacional do sociólogo fluminense.

Diante do problema da dispersão das populações e da estrutura "ganglionar" da sociedade brasileira, era preciso que os agentes políticos imperiais - vistos por Oliveira Vianna e Arthur Cézar Ferreira Reis como estadistas - resolvessem o problema da desorganização social e política que poderia conduzir à "hispanização" da América portuguesa, isto é, à sua fragmentação em pequenas repúblicas.

A escolha pela forma unitária foi acertada, pois teria impedido a desagregação e mantido as regiões unidas (REIS, 1966; 1982). Vemos aqui outra afinidade eletiva do autor: regimes unitários, com um governo central forte e capaz de manter a ordem social. Tal predileção intelectual e política o fariam se aproximar tanto da ditadura varguista do Estado Novo (1937-45) quanto da ditadura civil-militar de 1964.

A consolidação de independência produziu a necessidade de organizar uma Assembleia Constituinte para estabelecer as instituições políticas e as leis do país. Arthur Cézar Ferreira Reis a considerou representativa da vida política brasileira naquele período, embora muitas províncias não tenham conseguido enviar os seus representantes à Constituinte. Os debates teriam levado a excessos que dificultaram a formulação da Carta Magna, daí a sua dissolução pelo imperador:

O novo projeto devia ser, depois de considerado nas câmaras, apreciado por nova Constituinte. D. Pedro entendeu, no entanto, que se fazia necessária sua imediata aplicação, com o que a acusação de absolutista, que lhe pesava, perderia expressão. E a 25 de março de 1824, dispensada a participação de uma nova Constituinte, era outorgada, assumindo o imperador, com o gesto, um poder que devia ter cabido à Assembleia Constituinte, a dissolvida, e a que pensara em convocar. (REIS, 1982, p. 159)

A nossa primeira Constituição fora outorgada pelo imperador ao superar os debates exaltados da antiga Assembleia. O historiador em tela interpretou que o clima político da época tinha a necessidade de estabelecer as competências de todos os poderes. Ao seguir esse raciocínio, o autor chegou à conclusão de que a Constituição de 1824 estabelecera um grande rol de liberdade para os brasileiros.

Como se verifica na disposição do Artigo 179 e seus itens, em número de 35, a Constituição de 1824 assegurava aos brasileiros uma área de liberdade que extinguia a ordem que vigorava no período colonial e era agora uma confirmação de que o pensamento liberal mais avançado estava na consciência dos que a elaboraram. (REIS, 1982, pp. 161-2) 
Consequentemente, Reis descreveu a Carta Constitucional de 1824 como "peça magnífica" do espírito de liberdade gerado com as revoluções francesa e americana, e que teria como mérito a preservação da configuração social e política criada por Portugal, impedindo a desagregação do território.

A Constituição de 1824, evidentemente, era peça magnífica na linha de uma ordem jurídica que principiara com as revoluções Americana, Francesa e se estendera às Américas. E, o que é fundamental, a nosso ver, mantinha, na forma unitária adotada, a unidade nacional, assegurando os laços de solidariedade do continente arquipélago que Portugal criara e poderia ter sido destruído na hora grave da independência, como sucedera, será bom recordar, com as antigas colônias espanholas. A unidade importava no reconhecimento de que já éramos um povo certo de seu destino e esse destino alicerçado no quadro imenso, mantido, do espaço físico que tornáramos espaço político, por nós possuído sem reservas e hesitações. (REIS, 1982, pp. 163-4)

O dispositivo político, baseado no liberalismo, funcionava de forma ordeira. Sob o império foi iniciado o processo de urbanização, retirando gradativamente a população que estava dispersa pelas propriedades rurais. As cidades experimentaram um melhoramento dos serviços, atraindo a população. A ascensão do urbanismo representou nova configuração social no Brasil, iniciada ainda durante o império. Mas essa mudança de configuração não representou o fim do patriarcado rural, pois as classes abastadas provenientes do mundo rural possuíam negócios lucrativos nas cidades, caminhando de par em par com as classes opulentas típicas da urbanização (REIS, 1966).

\section{O fỉm da monarquia constitucional parlamentar e a inserção brasileira no século $\mathrm{XX}$}

Para Arthur Cézar Ferreira Reis, éramos em 1889 planta exótica na América, uma vez que o continente tinha gerado várias repúblicas independentes, enquanto que o Brasil era uma monarquia constitucional parlamentar. $\mathrm{O}$ autor reiterou a sua ideia de que o sistema monárquico era mais europeu que americano. No final do século XIX, o sistema institucional e político do império chegaram ao seu limite.

Garantira (...) a unidade, assegurando a estabilidade ao processo de continuidade do país, levado a uma condição de prestígio universal realmente ponderável. O Império era planta exótica, constituía exceção, mas exercera seu papel da maior importância para a vida nacional. (REIS, 1982, pp. 121-3)

Tendo exercido seu papel de manter o domínio unido, os episódios de quarteladas e revoltas não teriam sido a tendência do império, de forma 
que não se gerou no Brasil o fenômeno do caudilho. Não havia entre nós um espírito anárquico, como na América Espanhola. Éramos, segundo o autor, tão exitosos em nossa constituição como eram os Estados Unidos. Por isso, Reis reconheceu os méritos do regime monárquico, pois concluiu que, se tivesse sido a república o regime adotado logo após a Independência, haveria a desintegração do Brasil (REIS, 1966; 1982).

Ao refletir sobre a decadência do império, o autor se referiu ao livro de Oliveira Vianna, $O$ ocaso do império, compartilhando as opiniões do sociólogo fluminense sobre as causas da mudança de regime:

o poder pessoal exagerado, exercido pelo imperador, irritação dos políticos contra o imperador pela rotatividade do sistema do governo, burla eleitoral, que de certo modo desprestigiava o regime, abolição da escravatura, questão militar (REIS, 1982, p. 216).

Acrescenta, porém, mais outras razões no seu diagnóstico:

a questão religiosa e a propaganda positivista, que principiava a inquietar os espíritos mais novos para a experiência republicana, nas linhas do catecismo de Augusto Comte. O poder pessoal de $\mathrm{D}$. Pedro era uma consequência do que constava da Constituição em vigor - o poder moderador. Exercido com austeridade mas intensa e profundamente, dava a impressão de que, na realidade, o monarca era não um monarca constitucional limitado em seus impulsos e sua ação pelo rigorismo do texto institucional, mas um autocrata que ignorava as limitações legais para exercitar um governo acima das prerrogativas que lhe cabiam Os ministros, buscados no dualismo partidário, e só por exceção, em fases mais difíceis, em fórmulas de concentração imposta pelo bem comum da hora grave, não se sentiam no uso franco, natural, rotineiro, de suas competências (REIS, 1982, pp. 216-7).

Embora o imperador tivesse o seu poder limitado pelo texto constitucional, a sua atuação institucional causava estranheza na classe política, que sentia a ausência de liberdade de ação devido às competências do poder moderador. A natureza do poder emanado do imperador não se restringia apenas a ser um símbolo do estado, mas também possuía como prerrogativas governar e administrar. Aquela que seria Izabel I num eventual III Reinado foi analisada por Reis como alguém que tinha uma ênfase executiva até maior que o rei (REIS, 1982).

Conforme aponta o autor em pauta, tanto a destituição quanto a subida dos partidos conservadores e liberais ocorria como simples rotina, sem que houvesse qualquer novidade na plataforma de governo, ou reformas para o progresso material ou, ainda, a integração territorial do império: era uma atmosfera política sem aspirações e sem perspectivas.

Os partidos se descriam do imperador, acusando-o de dificultar-lhes a ação, ou de absolver-lhes a competência, de seu lado estavam também sem mais conteúdo para assegurar-se a 
confiança pública. Os pleitos eleitorais constituíam espetáculos degradantes, senão de corrupção, de mandonismo, de falsificação da verdade das urnas, através de processo que as reformas eleitorais não tinham podido refrear, corrigir, dignificar, moralizar. (...) era indicação visível de que tudo prenunciava a fraqueza da monarquia. Se ninguém a defendia! Se ninguém sentia satisfação em servi-la! (REIS, 1982, p. 218)

Igualmente, o autor criticava a forma como foi feita a abolição. Embora tenha ocorrido sem dificuldades administrativas, não se via o golpe contra a economia patriarcal. A libertação dos escravos teria sido feita de maneira brusca e antieconômica, não levando em conta a peculiaridade da produção econômica brasileira. Os libertos também não tiveram qualquer apoio para seu progresso material, passando a compor partes significativas dos marginalizados sociais. A escravidão foi abolida de forma romântica (REIS, 1982).

Diante do quadro de corrupção eleitoral, do mal-estar que a classe política sentia em relação ao poder moderador, da propaganda republicana, do positivismo, do suposto autocratismo da futura rainha Izabel I e de uma abolição que desorganizou a economia nacional, o desgaste do regime seria inevitável. Sem embargo, decaiu o regime monárquico que, sem a luta nem mesmo do próprio monarca, desfez-se pacificamente.

O fim do império e a instituição da república implicariam também nossa inserção na "família americana": deixamos de ser "planta exótica", rodeada por uma floresta de repúblicas para sermos finalmente uma nação como as outras do continente, destituída de dinastias e governada por representantes escolhidos pela vontade popular. A república fora proclamada sem o apoio coletivo, mas igualmente sem a oposição dos elementos servis, demonstrando que a monarquia teria encerrado o seu ciclo de poder político.

Pedro II, conduzindo-se serenamente em seu papel de rei constitucional, executara realmente uma "democracia coroada". Impusera-se à admiração e ao respeito nacionais. O sistema, todavia, perdera sentido, ultrapassado e sem mais ser considerado suficiente para a solução dos problemas, de toda espécie, que se vinham acumulando. A Constituinte reunida em 1891/2 votou a Carta Magna influenciada pelos textos norteamericano e argentino, àquele principalmente. As províncias transformaram-se em estados, com ampla autonomia política. A federação vencia. (REIS, 1966, p. 63)

Arthur Cézar Ferreira Reis tomou partido pelo fim da monarquia e pela emergência do novo regime republicano. A primeira já tinha assegurado o seu papel de manter o território unido durante o século XIX. Os novos problemas que surgiram - como maior autonomia das províncias e a modernização da economia - não poderiam ser realizadas dentro do 
horizonte da organização política monárquica. $\mathrm{O}$ autor, portanto, aproximou-se da historiografia positivista e republicana da primeira metade do século XX. Vencidas as forças monárquicas, como a revolta da Armada, a República efetivou a dinamização social que a nação precisava (REIS, 1966).

Embora fosse partidário da República e do fim do império, Reis via a mudança de um regime por outro como consequência natural da evolução social e política brasileira. Essa visão não o impediu de entender a descentralização e o federalismo como problemas para o contexto brasileiro, principalmente em um país composto por suas diversidades regionais, onde os estados estavam mais preocupados com seus problemas locais do que com as questões nacionais. Mesmo a reforma constitucional de 1926, segundo o autor, não levou em conta as características regionais do Brasil. As insatisfações que começaram a surgir - juntamente com a concentração demográfica advinda do urbanismo - foram o princípio do fim da I República. Assim, apontou a eclosão de 1930 como consequência mais profunda da dinâmica e evolução social brasileira. Assim como o império não respondia mais aos anseios da nação e precisou ser substituído, a I República também não respondia satisfatoriamente às mudanças que se operavam na vida pública nacional. Por esse motivo, a Revolução de 1930 - que teve no nosso autor um dos articuladores em solo amazonense - era benfazeja para o país (REIS, 1982; 1966).

\section{Considerações finais}

Arthur Cézar Ferreira Reis interpretou a formação brasileira como resultado evolutivo da colonização, entendida esta como acontecimento histórico positivo, pois trouxe a civilização para a então América incivilizada. A política de Portugal para o Brasil é vista a partir dos grandes atos administrativos, de um planejamento realista sobre uma região geograficamente e socialmente adversa. A independência é inserida dentro de um amplo processo de descolonização do mundo, embora coloque a ação das elites políticas e intelectuais como preponderantes.

O historiador defendeu a função social e política do império pela manutenção da união das províncias que haviam se unido durante as décadas que se seguiram à Independência. $O$ autor não se posicionou explicitamente contra a abolição, embora predicasse ter sido feita de forma irresponsável, por ter prejudicado a economia brasileira. A república, por sua vez, é abordada como algo inevitável diante da necessidade de ingresso do Brasil no século XX, do cansaço da forma monárquica e da necessidade de se integrar à "família americana” de repúblicas. 
A criação da nacionalidade obedeceu, portanto, a um processo cumulativo, cujas origens estão na colonização. A independência política e as lutas autonomistas do período colonial são, antes de tudo, o resultado dessa organicidade criada pelo português nos trópicos. Esse acontecimento "admirável" deveria ser reverenciado, pois gerou a nação brasileira, com seus relacionamentos de povos e culturas e com a política disciplinada e realista de Portugal.

A dominação portuguesa se justificou pela superioridade cultural que fez com que o reino ibérico pudesse juntar vários povos diferentes entre si para, sob a sua tutela, criar uma sociedade tropicalizada. Tendo a cultura lusitana como protagonista, os colonizadores deram ao mundo uma civilização herdeira da cultura ibérica única e adaptada ao contexto tropical; essa expansão do mundo europeu sobre a América é o ponto nevrálgico da nacionalidade brasileira. Nesse cenário, ocorreu o diálogo de Reis com Gilberto Freyre. Enquanto o sociólogo pernambucano pensava a miscigenação que colocava a cultura do negro e do índio em igualdade com a cultura europeia, o intelectual e político amazônida - embora admitindo a miscigenação brasileira - indicava a natural dominação da civilização europeia. No seu entendimento, a cultura produzida no Velho Mundo era superior às outras formas de sociedade supostamente "inferiores". Assim como Freyre, concordava com a positividade da miscigenação na formação do povo brasileiro. Contudo, enquanto para o autor de Casa-grande \& senzala este teria sido um processo guiado pela família patriarcal, para Reis, foi um acontecimento resultante da atuação do estado português, que viu na mistura de raças e culturas uma vantagem para o povoamento do território. $\mathrm{O}$ amazonense também afirmava que vicejou na região, assim como no Nordeste, o complexo patriarcal da casa-grande e da senzala, com a diferença de que este se manteve na Amazônia até meados do século XIX, mas adaptado ao sistema extrativista (SILVA LOBATO, 2009).

Sua apoteose por formas de estado centralizadas, por governos fortes sustentados por uma elite intelectual e política capaz de guiar a nação se refletem em sua interpretação tanto do Brasil quanto da Amazônia.

Deste modo, apoiou a ruptura oligárquica de Getúlio Vargas e foi um dos integrantes da junta revolucionária de 1930 no Amazonas. Em meados da década dos 1960, tornou-se aliado do regime civil-militar de 1964, chegando a ser nomeado pelo então presidente Castelo Branco governador interventor do estado amazonense entre os anos de $1964 \mathrm{e}$ 1967. Isso refletiu em sua atuação política e tecnocrática ao contribuir para a criação e a implantação da Operação Amazônia, que era um projeto de economia política para a região Norte. 
Diante do exposto, podemos dizer que Arthur Cézar Ferreira Reis foi um dos principais teóricos e propagandistas da modernização conservadora na Amazônia.

\section{Referências bibliográficas}

BURKE, Edmund. Reflexões sobre a revolução na França. São Paulo: Editora Edipro, 2014.

DANTAS, Hélio da Costa. Colonização e civilização na Amazônia: escrita da história e construção regional na obra de Arthur Reis. Dissertação (Mestrado) apresentada à Universidade Federal do Amazonas, 2011.

GOMES, Leila Margareth Rodrigues. Movimentos sociais na obra de Arthur Reis. Dissertação (Mestrado) apresentada à Universidade Federal do Amazonas, Manaus, 2009.

KIRK, Russell. A política da prudência. São Paulo: Realizações Editora, 2013.

MANNHEIM, Karl. Ideologia e utopia. Rio de Janeiro: Zahar Editores, 1972.

MERCADANTE, Paulo. A consciência conservadora no Brasil: contribuição ao estudo da formação brasileira. 3. ed. São Paulo: Nova Fronteira, 1980.

PACHECO, Alexandre. A narrativa heroico-nacionalista de Arthur Reis na representação da defesa da Amazônia pelos portugueses e lusobrasileiros em A Amazônia e a cobiça internacional - anos 196o. História da Historiografia, Ouro Preto, 2012.

REIS, Arthur Cézar Ferreira. Épocas e visões regionais do Brasil. Manaus: Edições Governo do Estado do Amazonas, 1966.

- Como governei o Amazonas. Manaus: Edições Governo do Estado do Amazonas, 1968.

Olympio, 1982.

Aspectos da formação brasileira. Brasília: Editora José

RIBEIRO, Odenei de Souza. Tradição e modernidade no pensamento de Leandro Tocantins. Manaus: Editora Valer, 2015.

RICUPERO, Bernardo. O conservadorismo difícil. In: FERREIRA, Gabriela Nunes; BOTELHO, André. Revisão do pensamento conservador: ideias e política no Brasil. São Paulo: Editora Hucitec, 2013.

SCHWARZ, Roberto. As ideias fora do lugar. In: SCHWARZ, Roberto. Ao vencedor, as batatas. São Paulo: Livraria Duas Cidades, 1988.

SCRUTON, Roger. Como ser um conservador. Rio de Janeiro: Editora Record, 2015 . 
SILVA LOBATO, Sidney da. Estado, nação e região na obra de Arthur Cézar Ferreira Reis. Diálogos - Revista do Departamento de História e do Programa de Pós-Graduação em História, v. 13, n. 3, 2009.

SOUZA, Lademe Correia de. Arthur Reis e a história do Amazonas: um início em grande estilo. Dissertação (Mestrado) apresentada à Universidade Federal do Amazonas, 2009.

TORRES, João Camilo de Oliveira. Os construtores do império: ideias e lutas do Partido Conservador brasileiro. Brasília: Edições Câmara, 2017.

Como citar:

GILENO, Carlos Henrique; MEDEIROS, Rodrigo Dantas de; SILVA, Ricardo Lima da. O pensamento conservador no Amazonas: a interpretação de Arthur Cézar Ferreira Reis sobre a formação do Brasil. Verinotio - Revista on-line de Filosofia e Ciências Humanas, Rio das Ostras, v. 25, n. 2, pp. 166-190, nov. 2019.

Data do envio: 13 abr. 2019

Data do aceite: 29 set. 2019 